\title{
Strategic Reading Instruction in EFL Contexts
}

\author{
Mahmood Kazemi \\ Faculty of Foreign Languages, University of Isfahan, Isfahan, Iran \\ Mohsen Hosseini \\ Faculty of Foreign Languages, University of Isfahan, Isfahan, Iran \\ Mohammadreza Kohandani \\ Faculty of Foreign Languages, University of Isfahan, Isfahan, Iran
}

\begin{abstract}
In foreign language settings, learning to read in English is one of the main goals for many students. To that end, students need to master a number of reading strategies to be able to comprehend text information. Thus, reading instruction should help students become strategic readers. Although, strategic reading instruction and its effect on students' comprehension and metacognitive abilities has recently received a lot of attention, the issue is less understood in relation to EFL (English as a foreign language) context. The present study aims to bring together the related research findings to provide a clearer picture of strategic reading instruction in EFL situations. Also, suggestions for future research are provided.
\end{abstract}

Index Terms — reading comprehension, strategic reading, strategic reading instruction, reading strategies, EFL

\section{INTRODUCTION}

As noted by Rivers (1981), most of the students who learn English as a foreign language will never have the opportunity to converse with native speakers; but they will have access to the literature and periodicals of scientific and technical material written in English which is, in fact, what they need to assist them with further studies or in their work; or even in their leisure time. In foreign language situations, where second language input sources are limited, reading becomes a viable means of developing second language ability (Gorsuch \& Taguchi, 2010) which, in turn, can facilitate or hinder academic success for many foreign language learners across educational contexts (Taylor, Stevens, \& Asher, 2006). Thus, in many foreign language settings reading is given special attention, due to the fact that reading is one of the most important language learning goals for many foreign language students (Grabe, 1991).

The main goal for reading is 'comprehension', and everything else is a means to this end (Goldenberg, 2011; Loew, 1984). Comprehension is to the ability to go beyond the words, to understand the ideas in a text and the relationships that exist between those ideas (McNamara, 2007). The key variables of reading comprehension include the reader as an active information processor, the activity of reading, and the text, all of which intersect to affect how well comprehension occurs (McIntyre, Hulan, \& Layne, 2011), and therefore teaching English as a foreign language can be considered a delicate job in that teachers need to understand the nature of reading and teaching methodology on the one hand, and the nature of learners and the context in which teaching of reading takes place, on the other hand (Phakiti, 2006).

Reading is, in fact, an extraordinary achievement when the number of levels and components that need to be mastered are taken into consideration (Graesser, 2007; Shang, 2010). According to Grabe (2009), "reading is a strategic process in that a number of the skills and processes are needed on the part of the reader to anticipate text information, select key information, organize and mentally summarize information, monitor comprehension, repair comprehension breakdowns, and match comprehension output to reader goals" (p.15). Thus, an important goal for reading instruction should be to help students become expert, or more strategic readers (Janzen \& Stoller, 1998).

In the past three decades, the fields of pedagogy and reading have focused on strategies, and strategies have been given an important role in reading behavior discussions. Expert readers apply a wide variety of comprehension strategies, i.e., routines and procedures used to better comprehend what is read. For instance, when active readers read the title of a given text, they may bring to the mind what they already know about that particular topic. They may predict the content of the passage. They may make mental images of the text. They may summarize the important points of what they read. They may ask self-questions about what they are reading. They know when the text is understandable and when it is not making sense. Strategic readers know how to repair breakdowns in comprehension. They also skillfully coordinate these strategies, taking into account what the reading task is, what they know about text content, and what type of text they are reading. However, weaker readers make use of a small variety of strategies and use them in a limited and repetitive manner. Overall, flexible use of a range of strategies is what differentiates between proficient readers and weak readers (Dole, Duffy, Roehler, \& Pearson, 1991; Graesser, 2007; Paris, Wasik, \& Turner, 1991).

In recent years, the emphasis has shifted from mere identification and classification of reading strategies to their actual application in the language classroom (Aghaie \& Zhang, 2012; Anderson, 2005; McNamara, 2010). Readers may 
become expert readers and learners and also develop a more positive attitude towards reading if they are explicitly taught effective strategies and trained to check and monitor their comprehension while reading (e.g., Dole et al., 1991; Janzen, 2003; McNamara, 2007; Pressley, 2006).

Strategic reading instruction practices include explaining what comprehension-supporting reading strategies are, and where, when, how, and why they can be used, as well as how they can be adapted to various situations, modeling strategic reading behavior, and providing feedback on student strategy use by teachers (Carrell, 1998; Janzen, 2003; Paris, Lipson, \& Wixson, 1983; Pressley, 2006). This kind of explicit instruction is intended to give students complete awareness that reading is an active process and that comprehension-fostering and monitoring activities are important (Paris et al., 1991). In strategic reading instruction, which is now fully supported by research as a means of helping students to become proficient readers, strategy use is integrated with the process of reading for meaning, and students are helped to apply strategies to increase their comprehension of text meaning (Janzen, 2003).

Closely related to the issue of strategic reading is the concept of 'metacognition' proposed by Flavell (1976). In fact, as Aksan and Kisac (2009) note, when the sources upon reading comprehension are examined, metacognition remains at the forefront. "Metacognition refers to all processes about cognition, such as sensing something about one's own thinking, thinking about one's thinking and responding to one's own thinking by monitoring and regulating it" (Papleontiou-louca, 2003, p. 12). There is a consensus among scholars that metacognition has two interacting components: knowledge of cognition, and regulation of cognition. With regard to reading comprehension, knowledge of cognition falls into three categories: (1) declarative knowledge (knowing what strategies are), (2) procedural knowledge (knowing how to apply strategies), and (3) conditional knowledge (knowing why and when to apply strategies). Regulation of cognition consists of the activities applied in order to control and regulate the reading process (Loew, 1984; Paris et al., 1983; Schraw \& Moshman, 1995). As can be seen knowledge of cognition and regulation of cognition are the essential elements and the focus of strategic reading comprehension.

However, it is important to note that despite the fact that the concepts of metacognition and strategic reading have received a great deal of attention from researchers in recent years, both concepts remain less understood in relation to EFL (English as a foreign language) reading comprehension. According to H. Fan (2009), metacognition and reading strategies have largely been neglected within the context of EFL reading. In the same vein, Zahedi and Dorrimanesh (2008) believe that, in general, there is little strategy training taking place at present, especially for EFL students, and the training that is taking place is blind training.

\section{THEORETICAL FRAMEWORK}

Traditional views of reading assumed readers, as passive recipients of text information, possessing a large number of sub-skills which automatically apply them to comprehend all kinds of texts; that is, it was assumed that reading comprehension occurred automatically (Dole, 2000; Dole et al., 1991). Then a conceptual shift to a cognitive model of learning in the 1970's led to a different view of the reader as a result of a rethinking about the underlying processes in reading comprehension. Cognitive views of reading comprehension indicate that reading is an interactive and comprehension is a constructive process and that expert readers are distinguished from weak readers by their flexible use of a set of activities to make sense of the text and to monitor and regulate their comprehension (Baker \& Brown, 1984; Dole et al., 1991). A cognitive view of reading submits that comprehension instruction should emphasize teaching students a set of strategies to use to comprehend a text with the goal of empowering students with a sense of conscious control, or metacognitive awareness, over a group of strategies so that they can use and adapt the strategies with any text they read (Pressley, Johnson, Symons, McGoldrick, \& Kurita, 1989).

\section{A. Processes Involved in L2 Reading}

As Kendeou, van den Broek, White, and Lynch (2007) note, "comprehension is not a unitary phenomenon but rather a family of skills and activities" (p. 28). Given the complexity of reading and its many purposes and properties, it can reasonably be concluded that the cognitive processes operating when one reads must also be complex. Led by this very complex processing, researchers have come to investigate reading in terms of its component skills providing a clear picture of the reading process and of how these component skills interact and collaborate to build comprehension (Grabe, 2009).

In reading bottom-up (or lower-level) and top-down (or higher-level) processes combine and interact to lead to comprehension (Barnett, 1989). Bottom-up reading is the mechanical, word-driven process in which readers move from lower-level processes, (e.g., interpreting graphic symbols) to higher-level processes (e.g., assigning meaning to words) (Phakiti, 2006; Stanovich, 1980). That is, readers pay attention to individual letters and words, sound them out, and eventually grasp the structure of and assign meaning to larger syntactic units (e.g., sentences). Lower-level (i.e., bottomup) processes are composed of a variety of complex skills (e.g., word-recognition, word-integration or syntactic parsing, and proposition formation) (Eskey, 2005). Top-down reading is the hypothesis-driven process in which readers, directed by their goals, expectations and strategic processing, actively control the comprehension process (Grabe, 2009). They generate hypotheses and use their background knowledge and experiences to make inferences. For example, they form predictions of what will come next, test their predictions and verify or adjust them. They resort to decoding symbols only when comprehension breaks down. 
It is important to note that describing certain skills as lower-level does not mean that they are simple or undemanding; rather, they are those skills that have the potential to become strongly automatized that is an essential condition for fluent reading (Stanovich, 1990). Also, according to Grabe (2009), no current model of reading depicts reading as a purely top-down or bottom-up process. In fact, readers are necessarily both top-down and bottom-up readers at all times. Fluent readers are always involved in automatic word-recognition and syntactic parsing skills.

Reading is interactive in two senses. On the one hand, there is the interaction between the reader and the text, in that readers use information from their background knowledge as well as information from the text to reconstruct the text information. On the other hand, there is a second level of interaction involving the simultaneous processing interaction between many component skills ranging from rapid lower-level automatic skills to higher-level strategic, comprehension skills. It is important to note that these two levels of interaction are complementary. That is, readers engage in processes ranging from automatic to conscious strategic processing to reach optimal reading performance (Alderson, 2000; Grabe, 1991; McLeod \& McLaughlin, 1986).

Automatic Processing: Automaticity is a very important issue in nearly every theory of cognitive skill acquisition in both first and second language situations. It has been argued that automaticity promotes fluency. Fluency, in turn, may increase learners' motivation to use the language and seek more L2 contact, and also may itself be a goal for learners as part of success in second language acquisition (Segalowitz, 2003).

Lower-level processing in reading includes the automatic recognition of orthographic, morphological, lexical, and syntactic patterns of the text and converting them to mental resources to support comprehension (Grabe, 2009). This automatic processing suggests that readers read without even being aware of these abilities and can decode text without thinking about them (Ashby \& Rayner, 2006; Kuhn \& Stahl, 2003; Phakiti, 2006). Since these routinized and automatized skills take up no space in readers' limited-capacity working memory, more memory space will be made available and readers will be able to better use their cognitive capacities to comprehend the text (Alderson, 2000). Thus this lower-level automatic processing makes ground for higher-level reading processes, such as using background knowledge, identifying main ideas, summarizing, paraphrasing, and predicting (Eskey, 1998). So, a main goal of second language instruction is to help learners develop automatic reading skills upon which efficient reading is greatly dependent (Alderson, 2000; Phakiti, 2006).

Strategic Processing: At some points in reading, the reader recognizes that the text is difficult (e.g., encountering unfamiliar words, syntactic structures, or topics) or that his/her goals are not being met. These cases require the reader to consciously and actively control his/her reading process through the use of appropriate strategies (e.g., assessing the situation, synthesizing and evaluating information, using contextual clues, skipping unknown words, rereading, etc.), individually or in combination, in order to improve reading achievement (Block \& Pressley, 2002; Carrell, Gajdusek, \& Wise, 1998; Phakiti, 2006).

Therefore, strategic processing can be defined as "conscious, deliberate, intentional and goal-directed processing individuals employ when using the target language" (Phakiti, 2006, p. 23). That is, strategic processing entails learners' awareness and what may in fact make 'strategies' distinct from skills and other processes is this component of awareness and conscious reflection rather than the nature of processes per se (Afflerbach, Pearson, \& Paris, 2008; Anderson, 2005; Carrell et al., 1998).

\section{B. Reading Strategies}

In general, many second language learning strategies have been identified and classified by different researchers (see for example, Naiman, Fröhlich, Stern, \& Todesco, 1978; O'Malley, Chamot, Stewner-Manzanares, Russo, \& Küpper, 1985; Oxford, 1990; Rubin, 1975). Studies of language learning strategy application, which deal with the influence of strategy training for different language skills (i.e., reading, listening, writing, and speaking), and different learners, indicate that strategy instruction is effective in improving students' performance on a wide range of problem-solving tasks (O'Malley et al., 1985).

In line with this relatively recent shift of attention to effective second language learning strategies, there has been much attention to identifying what more-proficient readers do while trying to understand what they read, including what strategies they apply and how, why, and when they use those strategies (Sheorey \& Mokhtari, 2001). Accordingly, in the last two decades, comprehension instruction and reading-strategies instruction have converged. As noted by Pressley (2006) and Grabe (2009), comprehension instruction now includes teaching students a set of strategies to use while they are trying to comprehend the main idea of the text, and combining these two goals through scaffolded discussions as the students are reading the text. This needs the identification of effective strategies that support comprehension.

Two lines of research have led to the identification of effective reading strategies: (1) Descriptive research reporting of what expert readers do while reading difficult texts (e.g., Othman \& Jaidi, 2012; Shang, 2010; Sheorey \& Mokhtari, 2001; Yau, 2009; Zhang \& Wu, 2009), and (2) Experimental research showing the effectiveness of teaching certain reading comprehension strategies to different groups of students (e.g., Aghaie \& Zhang, 2012; Janzen, 2003; Palincsar \& Brown, 1984; Salataci \& Akyel, 2002). These two research types have had, at least, two very important outcomes; first, students need to develop metacognitive awareness for text comprehension, and second, students need to learn a variety of effective reading strategies to use to comprehend texts (Grabe, 2009). 
Different scholars in the field of reading comprehension, drawing upon findings of multiple research studies in both L1 and L2 contexts, have proposed different taxonomies or lists of effective reading strategies which support comprehension most (e.g., Duke \& Pearson, 2002; Grabe, 2009; Graesser, 2007; Phakiti, 2006). For example, Grabe (2009) lists twenty major reading strategies (Table I).

TABLE 1.

TWENTY MAJOR READING STRATEGIES (GRABE, 2009, PP. 218,219)

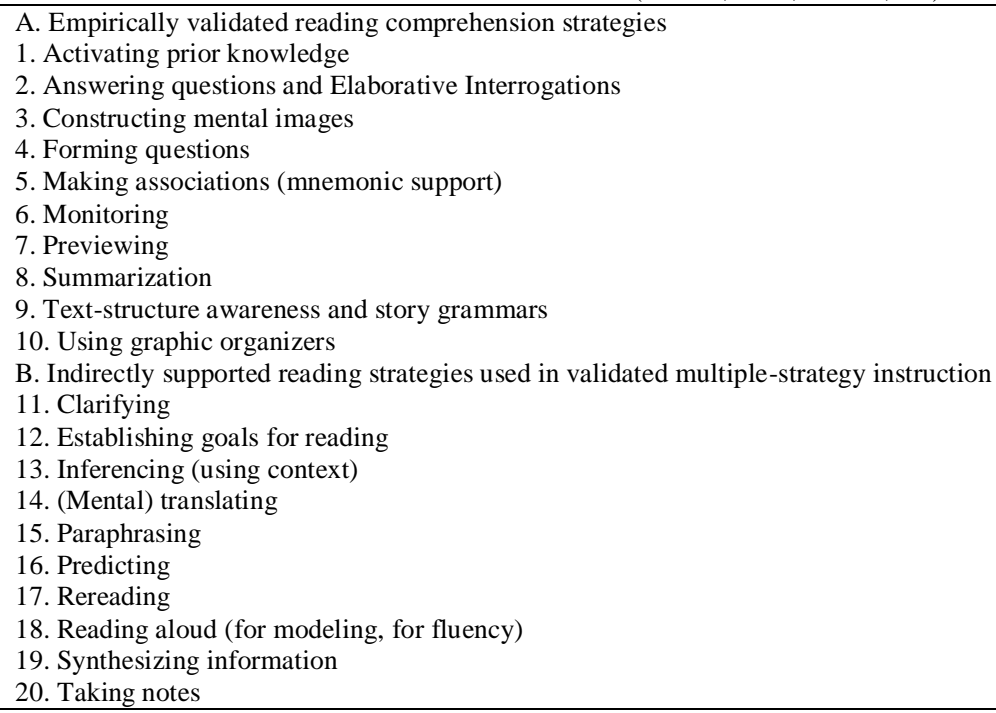

\section{Strategic Reading}

According to Grabe (2009), researchers dealing with reading instruction all acknowledge the centrality of strategy use and the development of strategic reader for comprehension. Strategic readers are readers who know a set of effective strategies and use them without continuously needing to move to a level of conscious problem solving but still can reflect consciously on a strategy when ask to do so and also know where, when, and why to use the strategies (Grabe, 2009; Palincsar \& Brown, 1984; Paris et al., 1983). While expert readers are characterized by strategic reading, novice and poor readers don't exhibit such behaviors (Paris \& Myers, 1981; Paris \& Oka, 1986; Wagoner, 1983).

Through L2 reading strategy research we have come to understand how strategic readers interact with what they are reading and how their strategic behavior results in their comprehension of a text (e.g., Anderson, 1991; Carrell, 1991; Salataci \& Akyel, 2002). Research has revealed that successful second language readers know how to apply effective strategies to better understand a text. They can read in different manners for different purposes (Arabsolghar \& Elkins, 2001), often jump back and forth in text and pay more attention to some parts of the text than to others, i.e., distribute their attention unequally (Pressley \& Harris, 2006). On the contrary, non-proficient poorer readers mostly read word by word in a linear way (Duke, Pressley, \& Hilden, 2004; Pressley \& Harris, 2006). They cannot use appropriate strategies for different goals and they generally don't possess metacognitive knowledge about and control over reading strategies and don't know how to approach reading (Baker \& Brown, 1984; Palincsar \& Brown, 1984; Paris et al., 1991; Yang, 2002). It is important to note that it is difficult to draw overall conclusions and generalize from research on L2 reading strategy use because of the many moderating variables (e.g., the interactive nature of L2 reading, learner characteristics, potential strategies, different contexts, differing manners and types of treatment and measurement, etc.) that potentially influence the results (Brantmeier, 2002; Grabe, 1991; Taylor et al., 2006).

\section{Strategic Reading Instruction}

Strategic reading instruction is instruction in the actual execution of reading strategies to reach the goal of reading comprehension (Bimmel, van den Bergh, \& Oostdam, 2001). The main characteristics of this instruction include: explaining what comprehension-supporting reading strategies are, and where, when, how, and why they can be used, as well as how they can be adapted to various situations, modeling strategic reading behavior, and providing feedback on student strategy use by teachers (Anderson, 1991; Carrell et al., 1998; Duke \& Pearson, 2002; Janzen, 2003; Paris \& Oka, 1986).

There is consensus among many reading researchers that teaching a combination of reading strategies (usually between four to eight strategies) more than individual strategy instruction improves comprehension and recall of information from texts (Baker, 2002; Block \& Pressley, 2007, 2002; Duke \& Pearson, 2002). There are several multiple-strategy instruction approaches which are supported by empirical research (e.g., Direct Explanation, Reciprocal Teaching, Collaborative Strategic Reading (CSR), Concept-Oriented Reading Instruction (CORI), Cognitive Academic Language Learning Approach (CALLA), etc.) (See Grabe, 2009, pp. 230-240, for a comprehensive description). 
In spite of the fact that combined-strategy instruction works better with students, there are several research studies which focus on finding the effects of individual reading strategies on students' performance. The following section deals with empirical research studies of strategic reading instruction, focusing on either individual- or multiplestrategies, in EFL contexts.

\section{EMPIRICAL StRATEgic READING RESEARCH IN EFL CONTEXTS}

Soonthornmanee (2002) set out to investigate whether reciprocal teaching helps Thai university students in comprehending texts and whether both skilled and less-skilled learners could benefit from this method. Reading strategies were taught to a group of 42 students through reciprocal teaching (RT) approach while a skill-oriented instruction was used with the other group of 42 students. According to the findings of the study reciprocal teaching could significantly influence EFL readers' reading performance. Moreover, although both skilled and less-skilled learners in the experimental group could benefit from reciprocal teaching method, the skill-oriented teaching method could only help the less-skilled learners in their reading comprehension.

Salataci and Akyel (2002) studied the effects of metacognitive strategies instruction on Turkish learners' comprehension of both Turkish and English. They wanted to see whether explicit teaching of metacognitive strategies could improve reading comprehension in Turkish EFL learners. Twenty university-level EFL learners in Turkey took part in the study. Pretests and posttests of both Turkish (i.e., their first language) and English (i.e., their foreign language) reading were administered to the participants. The study also included observations, interviews, and thinkaloud tasks. The students were trained in a three-hour class sessions for 4 weeks, on how to use metacognitive strategies. Results showed that the reading strategies used before and after the study were different: there was a decrease in the use of 'local strategies' (e.g., focusing on grammar or word meaning and using a dictionary) for reading in both Turkish and English after the instruction; but there was an increase in use of global strategies (e.g., skimming for main ideas, predicting, and summarizing) in reading in both languages.

Zarei (2002) conducted a quasi-experimental study with 74 Iranian university students to investigate the development and changes in students' conceptions of reading and metacognition processes and the effects these processes have on students' language proficiency and reading performance. The results of the study showed that a constructivist approach, i.e., instruction in metacognition, could help students develop a more comprehensive and sound base knowledge of the reading skill both at lower and higher levels compared with a transmission approach, i.e., traditional instruction in which no attention is paid to the students' construction of knowledge.

Taguchi and Gorsuch (2002) focused on exploring the transfer effects of Repeated Reading (RR) for silent reading rate and comprehension to new passages. The results of the study showed that the 10 -week RR program was able to increase the participants' (nine EFL Japanese university learners) reading rates from a pretest to a posttest of reading comprehension. However, the students' reading rate did not change significantly from the first RR session passage to the 28th (the last) session passage. In addition, participants from control and experimental groups showed similar transfer gains from pretest to posttest which was modest but not statistically significant. The short duration of the treatment was supposed by Taguchi and Gorsuch to be the reason for the lack of clear transfer effects for reading rate and comprehension of RR group readers.

Again, Gorsuch and Taguchi (2008 \& 2010) conducted two 11-week quasi-experimental RR studies with universitylevel students (i.e., 2008) and adult EFL learners (i.e., 2010) in Vietnam. In both of these studies Gorsuch and Taguchi offered evidence for positive effects of Repeated Reading (RR) strategy on participants' reading fluency and comprehension.

Cubukcu (2008) in his study instructed 130 third-year Turkish university students in metacognitive awareness for reading comprehension. The study aimed at determining the effectiveness of systematic explicit instruction of multiple metacognitive strategies through CALLA model on students' comprehending of texts. In an intact group, pretestposttest, experimental design, the students took part in a 45-minute reading comprehension training session each week for 5 weeks. The students in the experimental group $(n=65)$ wrote their reflections on their thinking processes while doing reading tasks in reading logs. Based on the results of the study, it was revealed that systematic direct instruction in metacognitive language learning strategies could develop reading comprehension. The students learned why, when, and how to use the strategies after being instructed in applying ten metacognitive language learning strategies in the training program. Also, they gradually started to think metacognitively about the strategies they could use which helped them become strategic and autonomous learners.

Akkakoson and Setobol (2009) aimed at promoting reading strategy use among tertiary level Thai students of science and technology in reading English texts. In the study, five issues were investigated: 1) the reading strategy use of Thai EFL scientific and technological students at three reading proficiency levels, i.e., high, intermediate, and low, 2) the effects of strategies-based instruction on learners' use of reading strategies to deal with English texts, 3) the extent to which the instructors help raise learners' awareness of using strategies in their reading, 4) the learners' attitudes towards using reading strategies, and 5) the problems of using strategies in learners' reading. Empirical data were collected from 207 undergraduate students, in six intact classes where the two researchers were the teachers themselves ( 3 classes each), by means of pre- and post-reading comprehension tests, an achievement test, as well as a questionnaire. The instruction was in the form of 3-hour lessons a week for 15 weeks during which forty four strategies were introduced. 
Students received explicit instruction in what each individual strategy is (declarative knowledge), the context or situation in which the strategy is to be applied (situational knowledge), and how to implement the strategy (procedural knowledge). The findings revealed positive effects of strategies-based instruction on learners' reading proficiency. Moreover, after the intervention, positive opinions towards reading strategies and utilizing them were given by the subjects.

H. Fan (2009) set out to explore how metacognitive strategies (i.e. think-alouds, text-structure, and summarization) could be employed most effectively by Taiwanese EFL university students to improve their reading comprehension. To this end, 143 freshman students at Lung Hwa University took part in the study. A 2-by-2 analysis of covariance (ANCOVA) measure was used to determine whether metacognitive strategy training could significantly improve the participants' reading comprehension. The analysis of results indicated that the experimental group who were engaged in metacognitive strategy use had better gains in reading comprehension than the control group.

In order to investigate the effect of reciprocal teaching on Iranian students' reading comprehension in general and on their ability to answer main idea and inference questions, Hadad (2009) conducted an empirical study with 60 intermediate students studying at an English institute. The students took pre- and post-tests of reading comprehension and also answered questionnaires provided to elicit their attitudes toward this method of strategy teaching. The results indicated that reciprocal teaching improved students' ability in reading comprehension in general, and their ability in answering main idea and inference questions in specific. The students had positive views toward the method and there was an increase in using some strategies by students at the end of the study.

Khajavi (2009) investigated the influence of concept-mapping, as a reading strategy, on reading achievement, selfefficacy, and self-regulation of Iranian university students of teaching English as a foreign language (TEFL). The treatment lasted for ten weeks. It was found through ANCOVA that students in the concept-mapping group showed greater achievement over time in reading comprehension, self-efficacy, and self-regulation strategies than students in the traditional method group.

Y. Fan (2010) investigated the effect of Collaborative Strategic Reading (CSR) on Taiwanese university students' reading comprehension with reference to specific types of reading comprehension questions. The participants were 110 students from two intact classes who had low-intermediate to intermediate level of English. This study adopted a pretest and posttest design with a control group. The data mainly came from statistical results of One-Way analysis of variance (ANOVA), but were triangulated by multiple data sets including the questionnaire responses and transcripts of group discussions during CSR. The findings indicated that CSR had a positive effect on the Taiwanese university learners' reading comprehension particularly in relation to the comprehension questions on getting the main idea and finding the supporting details.

Karbalaei (2011) examined the effect of teaching underlining strategy, through the CALLA model in EFL and ESL (English as a second language) contexts. He selected a random group of 189 college students studying at different universities in Iran and India. The participants were divided into high, moderate, and low levels based on their performance in a proficiency test. Then, the students were taught the underlining strategy for reading during the treatment sessions. The results suggested that both Iranian and Indian students performed better in multiple-choice reading comprehension tests after they were instructed in how , when, and why to underline information in a given text; although Indian ESL students had a better performance than Iranian EFL students. There was no significant interaction between students' proficiency level and their performance in reading comprehension in EFL and ESL contexts. In addition, there was no significant difference between males and females in the two contexts.

The purpose of a quasi-experimental study by Sun (2011) was to understand the effects of reciprocal teaching, as a means of reading strategy instruction, on Taiwanese EFL junior high school students' metacognitive awareness, selfefficacy, and reading comprehension in English. The 164 eighth-grade participants were divided into experimental (i.e. reciprocal teaching) and control (traditional reading instruction) groups. The instruction went on for a 10-week period. It was revealed through ANCOVA that students who were instructed in reciprocal teaching could improve more than students receiving traditional reading methods in reading comprehension, metacognitive awareness, and self-efficacy. The findings suggested that reciprocal teaching as a practical method of reading strategy instruction could enable students to develop an awareness of strategy use, increase self-efficacy levels, and most importantly, improve English reading comprehension.

Wichadee (2011), using a one-group pretest-posttest study with 40 Thai EFL learners at a private university over 14 weeks, tried to examine the effectiveness of explicit instruction of metacognitive strategies. Based on the results of the study, after the instruction the reading score and the metacognitive strategy use of the three groups (i.e., high, moderate, and low) were significantly higher than those before the instruction, indicating that metacognitive strategies instruction might have been an effective means to improve students' reading comprehension and strategy use.

Aghaie and Zhang (2012) investigated the influence of explicit teaching of reading strategies on EFL university students' reading ability in Iran. A questionnaire adapted from Chamot and O'Malley's (1994) cognitive and metacognitive strategies framework was used to collect the required data in this study. A quasi-experimental design involving a control group and an experimental group was used to test the effects of explicit teaching of cognitive and metacognitive reading strategies on students' reading performance and strategy transfer. After four months of strateg instruction, the experimental group achieved significantly better results than the control group. Results of paired- 
samples and independent-samples t-tests, effect sizes, and a Split-plot ANOVA showed that strategy instruction could lead to enhanced reading comprehension and reading strategy transfer and use. Moreover, strategy instruction could result in autonomous reading behaviors.

Jafari and Ketabi (2012) in their study investigated the effects of reading strategy instruction on enhancing reading comprehension in Iranian English-major university students. The results of the study indicated that the participants in experimental group significantly outperformed those in control group.

Mehrpour, Sadighi, and Bagheri (2012) investigated the potential of implementing reading strategy instruction in raising EFL readers' awareness of reading strategy use, increasing the number and type of strategies they employed and enhancing their reading comprehension ability. To conduct the study, 90 female pre-university students majoring in Natural Sciences were selected based on a convenient sampling procedure. A group of 53 students (experimental) was taught to employ reading comprehension strategies in reading some English texts during a period of 15 sessions while the other group of 37 students (control) was taught reading comprehension traditionally. The findings of the study revealed that reading strategy instruction was problematic in nature. Whereas strategy training was able to raise students' awareness of reading strategies and could encourage strategy use by some students, some strategies were found to be harder to be acquired. Moreover, based on the results of a reading comprehension posttest, the reading strategy instruction was not able to enhance the students' reading performance significantly.

\section{CONCLUSION}

According to above-mentioned studies, most researchers point to the necessity of teaching effective reading strategies to students so that they are able to enhance their reading achievement. By getting explicit instruction in effective strategies and learning to monitor and check their comprehension while reading, readers can become expert readers and comprehenders of whole text. Thus, the development of reading comprehension for EFL students is highly dependent of learning what strategies are, how, when, and where to use particular strategies, as well as how to evaluate their use.

The view of comprehension as the fluent implementation of strategic responses indicates the close relationship among comprehension, cognitive strategies, and metacognition. What this review of research reveals is that reading comprehension involves strategic responses to texts, but also that much more is needed (e.g., a combination of automatic word recognition, a large vocabulary, background knowledge, and extensive reading practice) in addition to comprehension strategies. As Anderson (1999) states, "the goal of explicit strategy instruction is to move readers from conscious control of reading strategies to unconscious use of reading skills" (p. 77).

But some gaps of knowledge can be observed with regard to the above-discussed studies. First, as can be seen and as noted by many researchers in the field (e.g., H. Fan, 2009; Grabe, 2009; Taylor et al., 2006), the number of published studies related to EFL contexts is very limited. Second, although research mainly indicates that strategic reading instruction is useful in improving reading comprehension among different groups of students (e.g., H. Fan, 2009; Jafari $\&$ Ketabi, 2012; Sun, 2011), there are studies with results which do not corroborate this finding (e.g., Mehrpour et al., 2012; Taguchi \& Gorsuch, 2002). Third, very few of the reviewed empirical studies focused on students' metacognition (just four studies, i.e., Akkakoson \& Setobol, 2009; Cubukcu, 2008; Mehrpour et al., 2012; Wichadee, 2011) and therefore the relationship between applying strategic reading instruction and students' metacognition seems unclear and demands much more clarification. And third, no study included, or at least mentioned, affective strategies in its choice of reading strategies.

Regarding what mentioned, much more research is needed in the area of strategic reading instruction in EFL settings before we can reach a valid conclusion about how strategy instruction may affect EFL students' reading comprehension performance and metacognitive abilities.

\section{REFERENCES}

[1] Afflerbach, P., Pearson, P. D. , \& Paris, S. G. (2008). Clarifying differences between reading skills and reading strategies. The Reading Teacher, 61.5, 364-373. doi: 10.1598/RT.61.5.1

[2] Aghaie, R., \& Zhang, L. J. (2012). Effects of explicit instruction in cognitive and metacognitive reading strategies on Iranian EFL students' reading performance and strategy transfer. Instructional Science, 40.6, 1063-1081. doi: 10.1007/s11251-0119202-5.

[3] Akkakoson, S., \& Setobol, B. (2009). Thai EFL students' use of strategies in reading English texts. The Journal of KMUTNB, $19.3,329-342$.

[4] Aksan, N., \& Kisac, B. (2009). A descriptive study: Reading comprehension and cognitive awareness skills. Procedia-Social and Behavioral Sciences, 1.1, 834-837. doi: 10.1016/j.sbspro.2009.01.149.

[5] Alderson, J. C. (2000). Assessing reading. Cambridge: Cambridge University Press.

[6] Anderson, N. J. (1991). Individual differences in strategy use in second language reading and testing. Modern Language Journal, 75, 460-472.

[7] Anderson, N. J. (1999). Exploring second language reading. Boston: Thompson \& Heinle.

[8] Anderson, N. J. (2005). L2 learning strategies. In E. Hinkel (ed.), Handbook of research on second language teaching and learning. Mahwah, NJ: Lawrence Erlbaum, 757-771.

[9] Arabsolghar, F., \& Elkins, J. (2001). Teachers' expectations about students' use of reading strategies, knowledge and behaviour in Grades 3, 5 and 7. Journal of Research in Reading, 24.2, 154-162. 
[10] Ashby, J., \& Rayner, K. (2006). Literacy development: Insights from research on skilled reading. In D. Dickinson \& S. Neuman (eds.), Handbook of early literacy research (vol. 2). New York: Guilford Press, 52-63.

[11] Baker, L. (2002). Metacognition in comprehension instruction. In C. Block \& M. Pressley (eds.), Comprehension instruction: Research-based best practices. New York: Guilford Press, 77-95.

[12] Baker, L., \& Brown, A. L. (1984). Metacognitive skills and reading. In P. D. Pearson (ed.), Handbook for reading research. New York, NY: Longman, 353-394.

[13] Barnett, M. A. (1989). More than meets the eye: Foreign language reading. Language and education: Theory and practice. Englewood Cliffs, NJ: Prentice-Hall Regents.

[14] Bimmel, P. E., van den Bergh, H., \& Oostdam, R. J. (2001). Effects of strategy training on reading comprehension in first and foreign language. European journal of psychology of education, 16.4, 509-529.

[15] Block, C., \& Pressley, M. (2007). Best practices in teaching comprehension. In L. Gambrell, L. Morrow \& M. Pressley (eds.), Best practices in literacy instruction (3rd edn.). New York: Guilford Press, 220-242.

[16] Block, C., \& Pressley, M. (eds.). (2002). Comprehension instruction: Research-based best practices. New York: Guilford Press.

[17] Brantmeier, C. (2002). Second language reading strategy research at the secondary and university levels: Variations, disparities, and generalizability. The Reading Matrix, 2.3, 1-14.

[18] Carrell, P. L. (1991). Second language reading: Reading ability or language proficiency? Applied Linguistics, 12.2, $159-179$.

[19] Carrell, P. L. (1998). Can reading strategies be successfully taught? Australian Review of Applied Linguistics, 21, 1-20.

[20] Carrell, P. L., Gajdusek, L., \& Wise, T. (1998). Metacognition and EFL/ESL reading. Instructional Science, 26.1-2, 97-112.

[21] Chamot, A. U., \& O’Malley, J. M. (1994). The CALLA handbook: Implementing the cognitive academic language learning approach. New York: Longman.

[22] Cubukcu, F. (2008). How to enhance reading comprehension through metacognitive strategies. The Journal of International Social Research, 1.2, 83-93.

[23] Dole, J. A. (2000). Explicit and implicit instruction in comprehension. In B. M. Taylor, M. F. Graves \& P. Van Den Broek (eds.), Reading for meaning: Fostering comprehension in the middle grades. New York: Teachers College Press, 52-69.

[24] Dole, J. A., Duffy, G. G., Roehler, L. R., \& Pearson, P. D. (1991). Moving from the old to the new: Research on reading comprehension instruction. Review of Educational Research, 61.2, 239-264. doi: 10.3102/00346543061002239.

[25] Duke, N. K., \& Pearson, P. D. (2002). Effective practices for developing reading comprehension. In A. E. Farstrup \& S. J. Samuels (eds.), What research has to say about reading instruction (3rd edn., vol. 3). Newark, DE: International Reading Association, 205-242.

[26] Duke, N. K., Pressley, M., \& Hilden, K. (2004). Difficulties with reading comprehension. In C. A. Stone, E. R. Silliman, B. J. Ehren \& K. Apel (eds.), Handbook of language and literacy: Development and disorders. New York: The Guilford Press, 501520 .

[27] Eskey, D. (1998). Holding in the bottom: An interactive approach to the language problems of second language readers. In P. Carrell, J. Devine \& D. Eskey (eds.), Interactive approaches to second language reading. New York: Cambridge University Press, 93-100.

[28] Eskey, D. (2005). Reading in a second language. In E. Hinkel (ed.), Handbook of research on second language teaching and learning. Mahwah, NJ: Lawrence Erlbaum, 563-580.

[29] Fan, H. (2009). The effectiveness of metacognitive strategies in facilitating Taiwanese university learners in EFL reading comprehension. Ph.D. dissertation, University of Kansas.

[30] Fan, Y. (2010). The effect of comprehension strategy instruction on EFL learners' reading comprehension. Asian Social Science, 6.8, 19-29.

[31] Flavell, J. H. (1976). Metacognitive aspects of problem solving. In L. B. Resnick (ed.), The nature of intelligence. Hillsdale, NJ: Lawrence Erlbaum Associates, 231-235.

[32] Goldenberg, C. (2011). Reading instruction for English language learners. In M. L. Kamil, P. D. Pearson, E. B. Moje \& P. P. Afflerbach (eds.), Handbook of reading research (vol. 4). New York, NY: Routledge, 684-710.

[33] Gorsuch, G., \& Taguchi, E. (2008). Repeated reading for developing reading fluency and reading comprehension: The case of EFL learners in Vietnam. System, 36.2, 253-278. doi: 10.1016/j.system.2007.09.009

[34] Gorsuch, G., \& Taguchi, E. (2010). Developing reading fluency and comprehension using repeated reading: Evidence from longitudinal student reports. Language Teaching Research, 14.1, 27-59. doi: 10.1177/1362168809346494.

[35] Grabe, W. (1991). Current developments in second language reading research. TESOL quarterly, 25.3, 375-406

[36] Grabe, W. (2009). Reading in a second language: Moving from theory to practice. New York, NY: Cambridge University Press

[37] Graesser, A. C. (2007). An introduction to strategic reading comprehension. In D. S. McNamara (ed.), Reading comprehension strategies: Theories, interventions, and technologies. Mahwah, NJ: Lawrence Erlbaum, 3-26.

[38] Hadad, A. (2009). On the effect of reciprocal teaching on reading comprehension of Iranian intermediate EFL learners. Unpublished M.A. thesis, University of Isfahan, Iran.

[39] Jafari, D., \& Ketabi, S. (2012). Metacognitive Strategies and Reading Comprehension Enhancement in Iranian Intermediate EFL Setting. International Journal of Linguistics, 4.3, 1-14. doi: 10.5296/ijl.v4i3.1684.

[40] Janzen, J. (2003). Developing strategic readers in elementary school. Reading Psychology, 24.1, 25-55. doi: $10.1080 / 02702710390147016$.

[41] Janzen, J., \& Stoller, F. L. (1998). Integrating Strategic Reading into L2 Instruction. Reading in a Foreign Language, 12.1, 251-269.

[42] Karbalaei, A. (2011). Assessing reading strategy training based on CALLA model in EFL and ESL context. Íkala, revista de lenguaje y cultura, 16.27, 167-187.

[43] Kendeou, P., van den Broek, P., White, M., \& Lynch, J. (2007). Comprehension in preschool and early elementary children: Skill development and strategy interventions. In D. McNamara (ed.), Reading comprehension strategies: Theories, interventions, and technologies. Mahwah, NJ: Lawrence Erlbaum, 27-45. 
[44] Khajavi, Y. (2009). Improving Iranian EFL learners' reading comprehension, self-efficacy and self-regulatory strategies: The effect of concept mapping instruction. Unpublished M.A. thesis, Univesity of Isfahan, Iran.

[45] Kuhn, M. R., \& Stahl, S. A. (2003). Fluency: A review of developmental and remedial practices. Journal of Educational Psychology, 95.1, 3-21. doi: 10.1037/0022-0663.95.1.3

[46] Loew, H. Z. (1984). Developing strategic reading skills. Foreign Language Annals, 17.4, 301-303.

[47] McIntyre, E., Hulan, N., \& Layne, V. (2011). Reading instruction for diverse classrooms. New York, NY: The Guilford Press.

[48] McLeod, B., \& McLaughlin, B. (1986). Restructuring or automaticity? Reading in a second language. Language Learning, 36.2, 109-123.

[49] McNamara, D. S. (2007). Reading comprehension strategies: Theories, interventions and technologies. Mahwah, NJ: Lawrence Erlbaum Associates.

[50] McNamara, D. S. (2010). Strategies to read and learn: Overcoming learning by consumption. Medical Education, 44.4, 340346. doi: 10.1111/j.1365-2923.2009.03550.x.

[51] Mehrpour, S., Sadighi, F., \& Bagheri, Z. (2012). Teaching Reading Comprehension Strategies to Iranian EFL Pre-University Students. Journal of Teaching Language Skills (JTLS), 4.1, 107-139.

[52] Naiman, N., Fröhlich, M., Stern, H. H., \& Todesco, A. (1978). The good language learner. Toronto: Ontario Institute for Studies in Education.

[53] O'Malley, J. M., Chamot, A. U., Stewner-Manzanares, G., Russo, R. P., \& Küpper, L. (1985). Learning strategy applications with students of English as a second language. TESOL quarterly, 19.3, 557-584.

[54] Othman, Y., \& Jaidi, N. H. (2012). The employment of metacognitive strategies to comprehend texts among pre-university students in Brunei Darussalam. American International Journal of Contemporary Research, 2.8, 134-141.

[55] Oxford, R. L. (1990). Language learning strategies: What every teacher should know. Boston: Heinle \& Heinle.

[56] Palincsar, A. S., \& Brown, A. L. (1984). Reciprocal teaching of comprehension-fostering and comprehension-monitoring activities. Cognition and Instruction, 1.2, 117-175.

[57] Papleontiou-louca, E. (2003). The concept and instruction of metacognition. Teacher Development, 7.1, 9-30.

[58] Paris, S. G., Lipson, M. Y., \& Wixson, K. K. (1983). Becoming a strategic reader. Contemporary Educational Psychology, 8.3, 293-316.

[59] Paris, S. G., \& Myers, M. (1981). Comprehension monitoring, memory, and study strategies of good and poor readers. Journal of Literacy Research, 13.1, 5-22.

[60] Paris, S. G., \& Oka, E. R. (1986). Children's reading strategies, metacognition, and motivation. Developmental Review, 6.1, 2556.

[61] Paris, S. G., Wasik, B. A., \& Turner, J. C. (1991). The development of strategic readers. In R. Barr, M. L. Kamil, P. B. Mosenthal \& P. D. Pearson (eds.), Handbook of Reading Research (vol. 2). New York: Longman, 609-640.

[62] Phakiti, A. (2006). Theoretical and pedagogical issues in ESL/EFL teaching of strategic reading. University of Sydney Papers in TESOL, 1, 19-50.

[63] Pressley, M. (2006). Reading instruction that works: The case for balanced teaching (3rd edn.). New York: The Guilford Press.

[64] Pressley, M., \& Harris, K. R. (2006). Cognitive strategies instruction: From basic research to classroom instruction. In P. A. Alexander \& P. H. Winne (eds.), Handbook of educational psychology (2nd edn.). Mahwah: Erlbaum, 265-286.

[65] Pressley, M., Johnson, C. J., Symons, S., McGoldrick, J. A., \& Kurita, J. A. (1989). Strategies that improve children's memory and comprehension of text. The Elementary School Journal, 90.1, 3-32.

[66] Rivers, W. M. (1981). Teaching foreign-language skills (2nd edn.). Chicago: The University of Chicago Press.

[67] Rubin, J. (1975). What the "good language learner" can teach us. TESOL quarterly, 9.1, 41-51.

[68] Salataci, R., \& Akyel, A. (2002). Possible effects of strategy instruction on L1 and L2 reading. Reading in a Foreign Language, 14.1, 1-17.

[69] Schraw, G., \& Moshman, D. (1995). Metacognitive theories. Educational psychology review, 7.4, 351-371.

[70] Segalowitz, N. (2003). Automaticity and second languages. In C. Doughty \& M. Long (eds.), The handbook of second language acquisition. Oxford: Blackwell Publishing, 382-408.

[71] Shang, H. (2010). Reading strategy use, self-efficacy and EFL reading comprehension. Asian EFL Journal, 12.2, 18-42.

[72] Sheorey, R., \& Mokhtari, K. (2001). Differences in the metacognitive awareness of reading strategies among native and nonnative readers. System, 29.4, 431-449.

[73] Soonthornmanee, R. (2002). The effect of the reciprocal teaching approach on the reading comprehension of EFL students. RELC Journal, 33.2, 125-141. doi: 10.1177/003368820203300206.

[74] Stanovich, K. E. (1980). Toward an interactive-compensatory model of individual differences in the development of reading fluency. Reading research quarterly, 16, 32-71.

[75] Stanovich, K. E. (1990). Concepts in developmental theories of reading skill: Cognitive resources, automaticity, and modularity. Developmental review, 10.1, 72-100.

[76] Sun, L. (2011). A study of the effects of reciprocal teaching as a reading strategy instruction on metacognitive awareness, selfefficacy, and English reading comprehension of EFL junior high school students. Ph.D. dissertation, La Sierra University.

[77] Taguchi, E., \& Gorsuch, G. J. (2002). Transfer effects of repeated EFL reading on reading new passages: A preliminary investigation. Reading in a Foreign Language, 14.1, 43-65.

[78] Taylor, A., Stevens, J., \& Asher, J. W. (2006). The effects of explicit reading strategy training on L2 reading comprehension. In J. Norris \& L. Ortega (eds.), Synthesizing research on language learning and teaching. Philadelphia: John Benjamins, 213-244.

[79] Wagoner, S. A. (1983). Comprehension monitoring: What it is and what we know about it. Reading Research Quarterly, 18.3, 328-346.

[80] Wichadee, S. (2011). The effects of metacognitive strategy instruction on EFL Thai students' reading comprehension ability. Journal of College Teaching \& Learning, 8.5, 31-40.

[81] Yang, Y. (2002). Reassessing readers' comprehension monitoring. Reading in a Foreign Language, 14.1, 18-42. 
[82] Yau, J. C. (2009). Reading characteristics of Chinese-English adolescents: knowledge and application of strategic reading. Metacognition and Learning, 4.3, 217-235. doi: 10.1007/s11409-009-9046-4.

[83] Zahedi, K., \& Dorrimanesh, P. (2008). Metacognitive learning strategies and academic success of TEFL MA Students in distance education. International Journal of Criminology and Sociological Theory, 1.2, 161-176.

[84] Zarei, G. (2002). A developmental study of EFL reading comprehension and metacognition processes: A constructivist vs. transmissional approach. Unpoblished Ph.D. dissertation, University of Isfahan, Iran.

[85] Zhang, L. J., \& Wu, A. (2009). Chinese senior high school EFL students' metacognitive awareness and reading-strategy use. Reading in a Foreign Language, 21.1, 37-59.

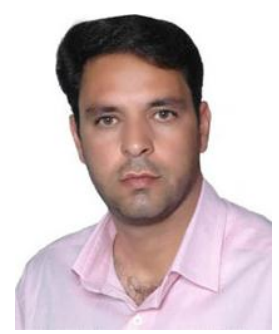

Mahmood Kazemi was born in Isfahan, Iran, in 1975. He got his BA in TEFL from the University of Isfahan, Isfahan, Iran, in 1999 and his MA from the same university in 2013.

He has been an English Teacher in Isfahan, Iran from 1999. His research interests are language teaching, psycholinguistics, and discourse analysis.

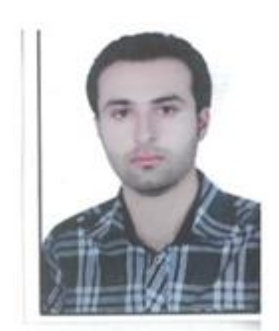

Mohsen Hosseini was born in Shahrekord, Iran, in 1987. He got his BA in TEFL from the University of Isfahan, Isfahan, Iran, in 2010 and his MA from the same university in 2013.

He has been an English Teacher in Isfahan, Iran from 2009. His research interests are language teaching, psycholinguistics, and discourse analysis.

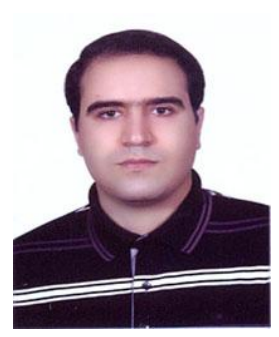

Mohammadreza Kohandani was born in Qom, Iran, in 1983. He got his BA in English Language and Literature from the University of Qom, Qom, Iran, in 2007 and his MA in TEFL from the University of Isfahan, Isfahan, Iran, in 2013.

He has been an English teacher in Qom, Iran since 2004. His research interests are Language teaching, CALL, and discourse analysis. 